\title{
sciendo
}

\section{Is the Czech Republic a Welfare State?}

\section{Christiana Kliková $^{1}$, Boris Navrátil ${ }^{2}$}

\begin{abstract}
Is the Czech Republic a welfare state? This question is to be answered through this article, whose purpose is to classify Czechia into one of the types of the welfare state. The introduction of the article describes the creation of the welfare state and the main factors influencing its origin. The article also describes the characteristic features of the welfare state and presents its typology. The section entitled "The Czech Republic and the welfare state" expounds on the constituent stages of development of the Czech social policy until the present day. The article concludes with the comparison of some aggregate indicators and characteristics of social policies found in Sweden, Germany and the United Kingdom with similar indicators from the Czech Republic; this basis forms the assignment of the Czech Republic to one of the types of the welfare state.
\end{abstract}

\section{Keywords}

Welfare State, Economic Policy, Social Policy, Public Social Services

\section{Introduction}

The welfare state, whose origin is associated with the name of William H. Beveridge, has undergone many a transformation during its existence. Its heyday occurred in the 1950s and 1960s, driven by economic growth and a relatively high employment rate in Western European countries, which allowed the expansion of the existing and the emergence of new social services and measures. Social benefits in this period, however, did no longer concern just the poor in those countries (as in previous years), but they began to be applied on a wide scale to the middle class as well. When the oil crises emerged in 1973 and 1979, the Western countries experienced a downturn of their economic activities, which deepened and led to the current crisis of the European welfare state. The current situation of the welfare state, however, is not only caused by a slow economic growth but is influenced by other factors too, including in particular:

\footnotetext{
${ }^{1}$ Vysoká škola PRIGO, Vítězslava Nezvala 801/1, 73601 Havírov, Czech Republic. E-mail: klikova@ prigo.cz.

2 Vysoká škola PRIGO, Vítězslava Nezvala 801/1, 73601 Havî́ov, Czech Republic. E-mail: navratil@prigo.cz.
} 
* relatively high unemployment rate in developed countries,

* family function being reduced,

* continued decline in birth rates,

* ageing of the population,

* increasing budget strains caused by increasing pension and health care spending,

* deepening government budget deficits,

but also the effects of globalisation, which are manifested in the social sphere mainly by the government's decreasing role in the society ${ }^{3}$, which causes serious issues: the fact is that a characteristic trait of the welfare state is the transfer of a substantial part of social activities to the state. ${ }^{4}$ In this sense, we can "with some exaggeration" state that every modern state (including Czechia) is actually a welfare state. Nonetheless, let us examine this statement in more detail.

\section{Development of the welfare state}

The welfare state ${ }^{5}$ can be generally understood as an example of one of the highest forms of interventionism in the market environment. According to Večeřa (1993), the basic preconditions for the existence of a welfare state are:

* existence of multi-party democracy,

* liberal economy,

* some minimum power decentralisation of the government and state administration.

But what does the "welfare state" (the state of public social services ${ }^{6}$ ) mean? How do we define it?

Put very simply, the welfare state strives to secure the conditions of "decent life" for all of its citizens. However, the definition of the term is difficult and inconsistent, which is mainly due to the diversity of forms of the welfare state and the diversity of perspectives on its nature; different theorists have not yet agreed on a uniform and comprehensive definition. They do agree, though, that in the strict sense, the welfare state represents a certain range of provision of key public social services (especially related to health, education, housing, income and, if needed, care services).

Keller (2011) is convinced that “... the welfare state was created. . . primarily so that all citizens could get about as much safety and security as is guaranteed to the wealthy by their wealth..."

Večeřa (1993) defines the welfare state as “. . . a state in which the democratically organised power through social legislation and state administration:

\footnotetext{
${ }^{3}$ This may lead to a state crisis that can result in “. . . its inability to act as a strong and decisive interlocutor of social mediation... " (Bauman, Bordoni, 2015).

${ }^{4}$ Another problem of the current globalisation trend is migration processes, which mainly concern countries with forthcoming social policies.

5 According to Ryneš, the term of the "welfare state" was coined only after World War II (Ryneš, 2015).

${ }^{6}$ Potůček (1995).
} 
* guarantees a minimum income for individuals and families at the level of living wage,

* provides social security that allows to prevent, mitigate or overcome social risks in order to ensure a reasonable minimum level of social security and social sovereignty,

* ensures a high level of adequate services for all citizens without making any distinctions as to the social status..."

Potůček (1995) identifies the welfare state as “... a state in which the laws and the people's consciousness and attitudes are asserted by the idea that the social conditions in which people live are not matters of individuals or families but they are a public affair... " In his later work (2010), he states that “... The welfare state is based on the idea that the social conditions of an individual are not just his and his family's matter, but also a matter of the society... " According to Krebs (2010), a hallmark of the welfare state is its strong public sector, or we can perceive it as a state that is looking for a third way between a centrally managed economy and a free market economy. Pick (2004) formulates the welfare state as “... a state which, in a developed form . . . regulated also the creation of resources, macroeconomically intervened in the stimulation of demand as well as micro-economically in the competitiveness of businesses... . was not just a political compromise between the left and the right or between socialism and capitalism. It was a new, viable model... ",

A. Giddens already perceives some weaknesses of the welfare state because he claims that "... the welfare state is essentially undemocratic and is based on the distribution of top-down benefits. Its motive is protection and care, but it does not leave enough space for personal freedom. .. " (Giddens, 2001). Musil (1996) views the welfare state in terms of social law and understands the welfare state as " $a$ situation in which the citizens of a modern state, at the time when their ability to secure the expected economic or social assistance to themselves or to those who depend on them is weakened or lost, are not dependent on voluntary assistance provided by their relatives and fellow citizens and have a legal right to be given assistance... "

According to Kvapilová (2010), the emergence of social law was conditioned by adopting social legislation, its development in England and Germany being different. In England, fundamental civil rights (freedom of speech and religion, freedom to sell, freedom to work freely) were created first, followed by political rights and social rights (with the adoption of social legislation); in Germany and Austria, social law was established first and then there were introduced civil and political rights.

Although individual social laws appeared in many countries even before the birth of the welfare state, the first ideas about it are associated with the works by J. Locke, T. Hobbes, J. J. Rousseau and J. Mill, and they can be traced also in the thoughts and ideas of the French Revolution. The state, however, had a very limited role in social policy until the end of 19th century. It was only the so-called Bismarck's social reforms carried out in Germany $^{7}$ and the implementation of similar reforms in Austria-Hungary (the so-called Taaffe's reforms) which started to largely shape the future system of social security;

\footnotetext{
${ }^{7}$ Between 1883 and 1889, the compulsory sickness and accident insurance was introduced as well as retirement and disability pensions.
} 
therefore, they are considered to be the first manifestation of the state's comprehensive action in the social sector and the first step towards the welfare state. However, the creation of the welfare state is associated with W. H. Beveridge ${ }^{8}$, who used this term for the first time in 1942 to call his model of the universal minimum social security.

Ryneš (2015) combines the creation of the welfare state with the gradual fulfilment of the following requirements:

* mutual help and assistance

* provision of help to the needy

* addressing human misery, hunger, helping the sick and the helpless

* foundation of workhouses, foundling-hospitals and hospitals managed by the church

* formation of associations of mutual self-support

* foundation of charity organisations on a religious basis

* the state's involvement in the sense of taxes for the rich in order to deal with homelessness

* working hours adjustment, efforts to tackle unemployment at both the business and the state levels

* emergence of social and state law-making

* emergence of charity and association activities and insurance

The causes that led to the creation of the welfare state are mostly (Krebs, 2010): advance in scientific knowledge, introduction of new technologies, orientation towards the cultivation of human factor, change of relations between the individual and the state and the limitation or exclusion of the traditional ways of addressing the social assistance through one's own power. The Swedish sociologist Walter Korpi (1983) unites the creation and development of the welfare state with the belief that it is primarily determined by political events. According to him, what is crucial for the development of the welfare state is the mobilisation of left-wing political parties and trade unions. The extent of the welfare state depends on its success and not on the degree of industrialisation. By contrast, Večeřa (1993) states that most concepts of the welfare state explain its genesis just by the social consequences of the industrialisation process and the emergence of industrial society.

\section{Types of the welfare state}

Despite the fact that individual welfare states have some characteristics in common (state interventions in the social sphere, high degree of redistribution, etc.), the social system is shaped differently. Therefore, different countries understand the concept of the welfare state differently, which is influenced by natural conditions, social conscience, traditions, religious perceptions, prevailing customs, culture, historical development, etc., which has

\footnotetext{
${ }^{8}$ William Beveridge worked as the director of the London School of Economics and Political Science and was the chairman of the state committee of the British Parliament; with his team, he created a comprehensive, elaborated and interconnected system of measures for Churchill's government that aimed at providing employment, health care and a minimum standard of living for all citizens of the United Kingdom.
} 
inevitably led to the emergence of different types of the welfare state. According to the socio-economic nature, it is most often divided into the following types: liberal, corporate and social-democratic. As Tomeš states (2010, p. 329), the classification of countries is based on the state-employer-citizen relationship. Specifically, " . . the state either:

* provides its citizens with a dignified living minimum through the public social protection, and the rest needs to be taken care of by the citizen's diligence - the residual (liberal) model,

* the state transfers the burden of social protection to employers and citizens - the performance (corporate) model,

* the state takes responsibility for a comprehensive, adequate social protection of its citizens to safeguard their inherent human rights - the institutional (socialdemocratic) model..."

The characteristics of the models are shown in Table 1.

Table 1: Characteristics of types (models) of the welfare state

\begin{tabular}{|l|c|c|c|}
\hline Welfare state type & Residual & Performance-related & Institutional \\
\hline Characteristic & liberal & conservative & social-democratic \\
\hline $\begin{array}{l}\text { the state's responsibility for } \\
\text { fulfilling the needs }\end{array}$ & minimum & optimum & complete \\
\hline $\begin{array}{l}\text { distribution according to the } \\
\text { needs }\end{array}$ & marginal & secondary & primary \\
\hline $\begin{array}{l}\text { range of obligatorily provided } \\
\text { services }\end{array}$ & limited & extensive & complete \\
\hline $\begin{array}{l}\text { population covered } \\
\text { obligatorily by provided } \\
\text { services }\end{array}$ & minority & majority & everyone \\
\hline amount of contributions & low & medium & high \\
\hline $\begin{array}{l}\text { part of the national income } \\
\text { intended for the state services }\end{array}$ & low & medium & high \\
\hline neediness examination & primary & secondary & marginal \\
\hline nature of the society's clients & the poor & citizens & members \\
\hline clients' status & low & medium & high \\
\hline specific country - example & United Kingdom & Germany & Sweden \\
\hline
\end{tabular}

Source: Jones (1985) in Potǔček (1995), Krebs (2010), Keller (2011)

This typology was used also by the Danish theorist Gosta Esping-Andersen (1990) as the basis for his own differentiation of welfare states, later adding a fourth type - Southern European. ${ }^{9}$

\footnotetext{
${ }^{9}$ In our case, however, his typology of welfare states will not be dealt with. The classification shown in the table is sufficient for the purposes of this paper.
} 


\section{Czech Republic and the welfare state}

The development of social policy from the establishment of the independent Czechoslovak state to the present will be addressed first. Then there will be compared the selected indicators of the countries that represent each type of the welfare state with the value of the same indicators for the Czech Republic. Based on this comparison, it is possible to conclude whether the Czech Republic is a welfare state and which type it leans forward.

\section{Development of social policies in the Czech Republic}

In terms of creating the social infrastructure, the Czech or more precisely the Czechoslovak state was not formed on a "green field" after 1918; it adopted some laws and standards from Austria-Hungary, which were gradually modified. Specifically, it involved accident insurance for workers, old-age and sickness insurance and a rent control programme.

\section{Social policy during the first republic}

After the end of World War I, there were adopted laws on unemployment benefits, eight-hour working hours and the disbursement of pensions to disabled veterans and the bereaved of the fallen. In 1924, sickness insurance was reformed, and disability and oldage insurance of the workers employed in the private sector was codified. The economic crisis of the 1930s slowed down, or more precisely decreased social activities: e.g. the state aid scheme for the unemployed was modified so that only union members were entitled to the benefits; the housing protection programme ${ }^{10}$ was gradually reduced until 1937 when it was completely abolished.

\section{Social policy between 1945 and 1989}

Generally speaking, the whole system of social policy following 1945 was reformed and was characterised in particular by being based on full employment, with labour being enforced by law; the state became the basic and monopolistic entity of social policy. Another typical feature of this stage of development was the abuse of social policies also in order to keep the citizens loyal to the regime.

The ideas of guaranteeing social security were strengthened after World War II. In 1947, a comprehensive social insurance scheme was adopted for all employed persons and the National Insurance Company was founded. In terms of social insurance, four types were distinguished: accident, old-age, sickness and unemployment insurance. For old-age pensions, people were divided into three categories according to the sector in which they worked (the retirement age differed). Since "poverty was abolished", benefits for the poor did not exist; although, they were later reintroduced but without legal support, which means that they did not officially exist until 1991 (Kvapilová, 2010). From the 1950s to the 1980s, the state-funded social services were distributed through employers. In 1974, the family policy was reformed to promote a higher natality rate (the so-called Husák's

${ }^{10}$ The housing protection programme determined the amount of rent and specified the reasons for eviction. 
children). It may be said that there existed a "welfare state" during this period, called as "Leninist model of the welfare state"

\section{Social policy after 1989}

After 1989, it was necessary to adapt the then welfare system to market conditions, while the following changes were fundamental in how social-policy institutions worked in the overall framework:

* abolition of the obligation to work and the abolition of the "right to work",

* abolition of the state's monopoly on organising and providing social services,

* reform of social security and health care based on compulsory insurance (Potůček, 1995).

Leading experts prepared the Czech Social Reform, whose priorities were the following (Potůček, 2002):

1. work and development of human potential,

2. family and the labour market,

3. education and the labour market,

4. elimination of discrimination,

5. support of the development of the civil society and the non-profit sector,

6. promotion of trust and reciprocity, responsibility and security within the arrangement of the social protection system.

Following this basis, a social reform was subsequently prepared, focusing mainly on:

* active employment policy,

* liberalisation and pluralisation of the social security system,

* establishment of a rescue social security net (Potůček, 1995, p. 119).

The transformation of the social policy included all of its areas: employment policy, social security policy, which covered social insurance, welfare state support and social assistance, health care policy, education policy, housing policy and family policy.

In addition to these fundamental visible changes, the way how people thought and behaved had to be changed as well so that they were willing to assume responsibility for their destiny, not relying solely on the state. Interesting consequences may be also found in Macková, Kotlán (2017) or Macková (2015).

\footnotetext{
${ }^{11}$ The Leninist model of the welfare state was closely connected with the regimes in Central and Eastern Europe: the state had a monopoly on the provision of social services, but social assistance was given only to those who were part of the "working people" (the others were excluded from the system), and social and particularly civil rights were restricted.
} 


\section{Comparison of selected indicators of the social policy in some countries}

Table 1 outlines the characteristics of the welfare residual state, represented by the United Kingdom, the performance welfare state represented by the Federal Republic of Germany and the institutional welfare state represented by Sweden. Let us now compare the selected social spending of these countries between 1990 and 2018 with the social spending of the Czech Republic.

The total public social spending as a percentage of the countries' GDP is shown in Figure 1. The tendencies in public social spending in the Czech Republic correspond to those of the United Kingdom, except for the year 2000 when the Czech Republic had its total public social expenditure, expressed as a percentage of GDP, higher than the UK; as it is evident, the trend is the opposite in the remaining years: the United Kingdom pays a higher percentage of its GDP for social spending than the Czech Republic ${ }^{12}$.

Figure 1: Overall public social spending of the selected countries between 1990 and 2018 as a percentage of GDP

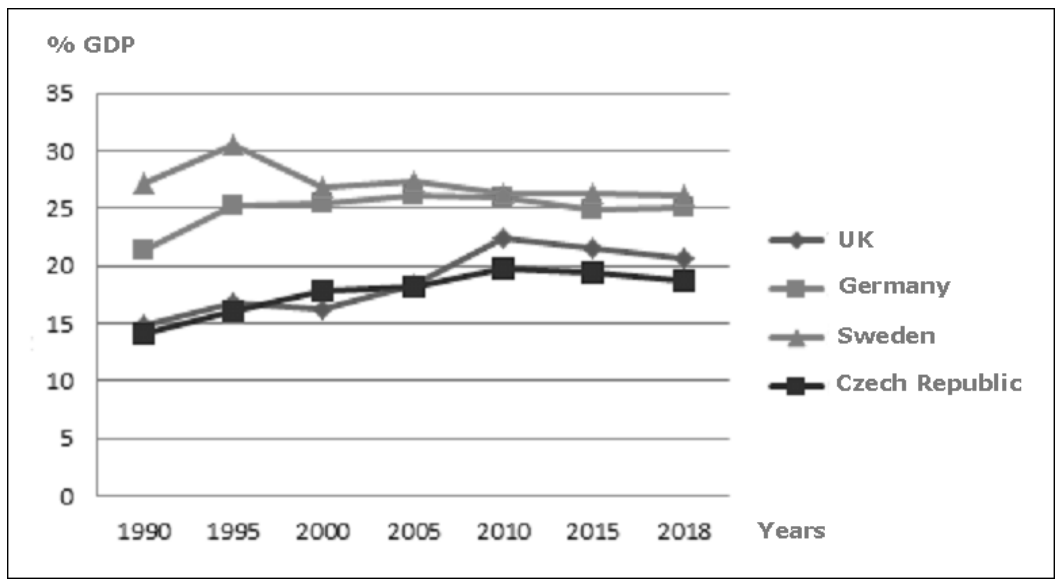

Source: OECD (2019), own adaptation

Note: this is a data estimate for 2017-2018.

Summary public expenditure for old-age and survivors' pensions, expressed as a percentage of GDP, is shown in Figure 2. This graph also shows a similar trend of these expenditures in the United Kingdom and the Czech Republic, again with the exception of 2000 when the spending of Sweden and the Czech Republic came closer together.

$\overline{12}$ One needs to realise, however, that these are relative indicators. 
Figure 2: Total public expenditure for old-age and survivors' pensions between 1990 and 2015 as a percentage of GDP

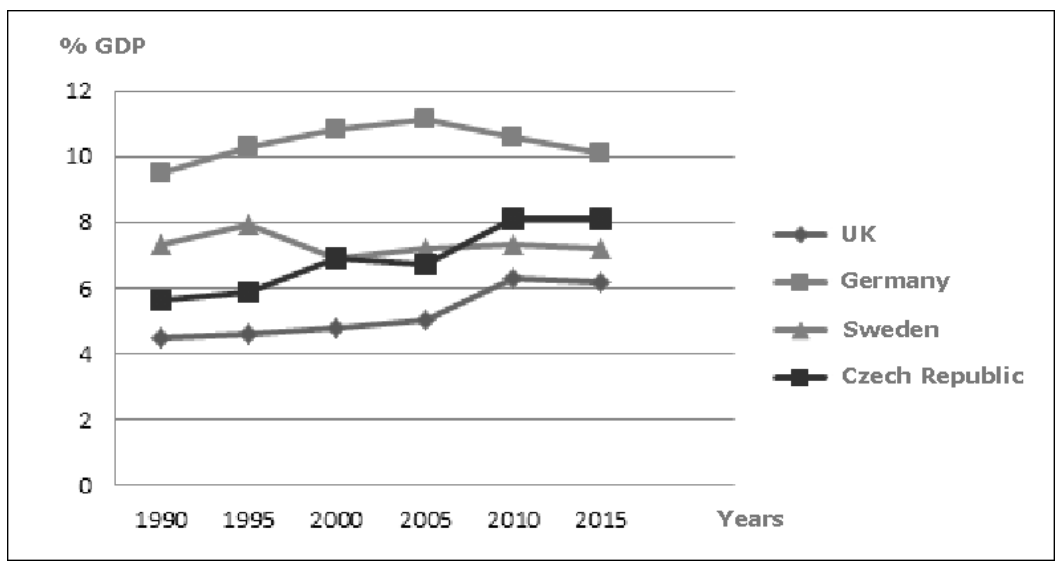

Source: OECD (2019), own adaptation

Total public expenditure for disability pensions and sick benefits as a percentage of GDP is shown in Figure 3. In this case, the spending as a percentage of GDP in the UK, Germany and the Czech Republic at the beginning and throughout the monitored period varies considerably as compared with Sweden; only at the end of the period does the spending as a percentage of GDP of each country converge.

Figure 3: Total public expenditure for disability pensions and sick benefits between 1990 and 2015 as a percentage of GDP

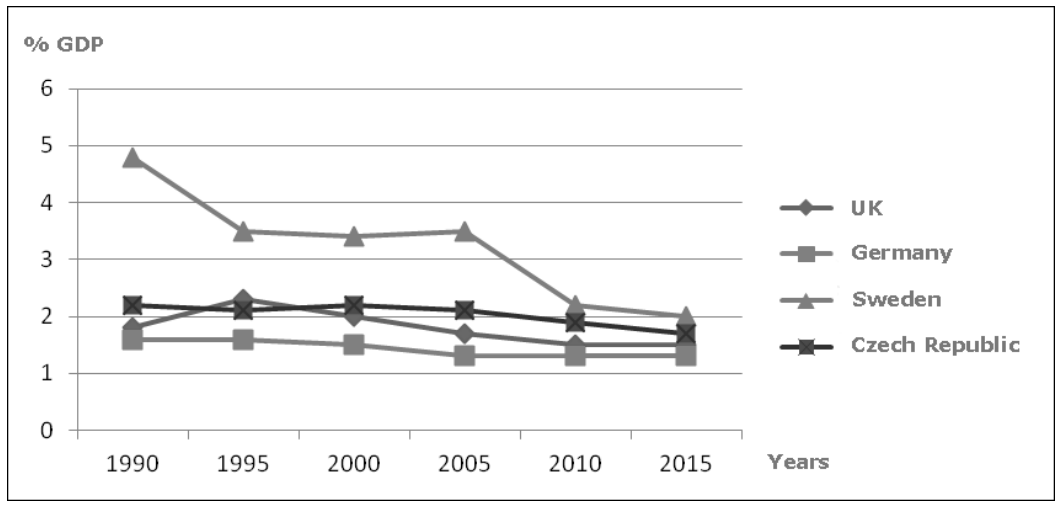

Source: OECD (2019), own adaptation

Total public expenditure for families as a percentage of GDP is shown in Figure 4. This clearly shows that the United Kingdom and Sweden differ from the rest of the countries throughout the entire monitored period. 
Figure 4: Total public expenditure for families between 1990 and 2015 as a percentage of GDP

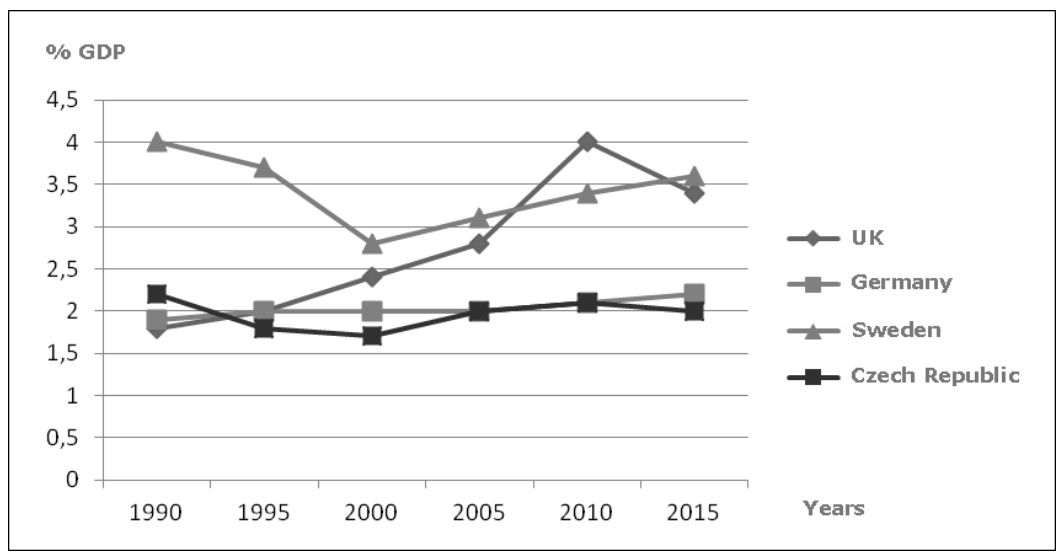

Source: OECD (2019), own adaptation

The presented graphical data show that the Czech Republic cannot be unequivocally classified into one particular type of the welfare state. Nevertheless, it is obvious that it will not be part of the institutional (social-democratic) type, whose characteristics do not correspond with the Czech Republic at all. It can therefore be assumed that the Czech Republic will oscillate between the liberal and the conservative type of the welfare state, considering also its other features:

* Czechia has long been one of the countries with the lowest poverty and social exclusion rates in the EU. The overall risk of income poverty and social exclusion in 2017 was 12.2 percent of the population; a person falls into income poverty when not reaching even 60 percent of the median income. Around 960000 Czechs lived below the income poverty line in 2017 (Czech Statistical Office, 2018). The people at risk of poverty and social exclusion, however, consisted of nearly one third of single mothers with children and elderly women over 65 .

* The survey of the Czech Statistical Office also showed that about 67 percent of households can save money each month. Two thirds of elderly persons living alone manage to save money regularly. By contrast, every other single parent living with a child cannot do it.

* Housing loans are paid by around a fifth of Czech households. They mostly include couples with children. Even low-income households do not shun mortgages and building loans.

* According to the Czech Statistical Office, health care costs at a doctor do not represent any burden for most households. However, 11.7 percent of households has problems with paying for prescribed medicines and about 9 percent of citizens has difficulties to pay the costs at the dentist. 
The unemployment rate in the Czech Republic has also been the lowest among the EU countries in recent years. The unemployment rate in the Czech Republic since 2014 up to the present is shown in Figure 5.

Figure 5: Unemployment rate in the Czech Republic

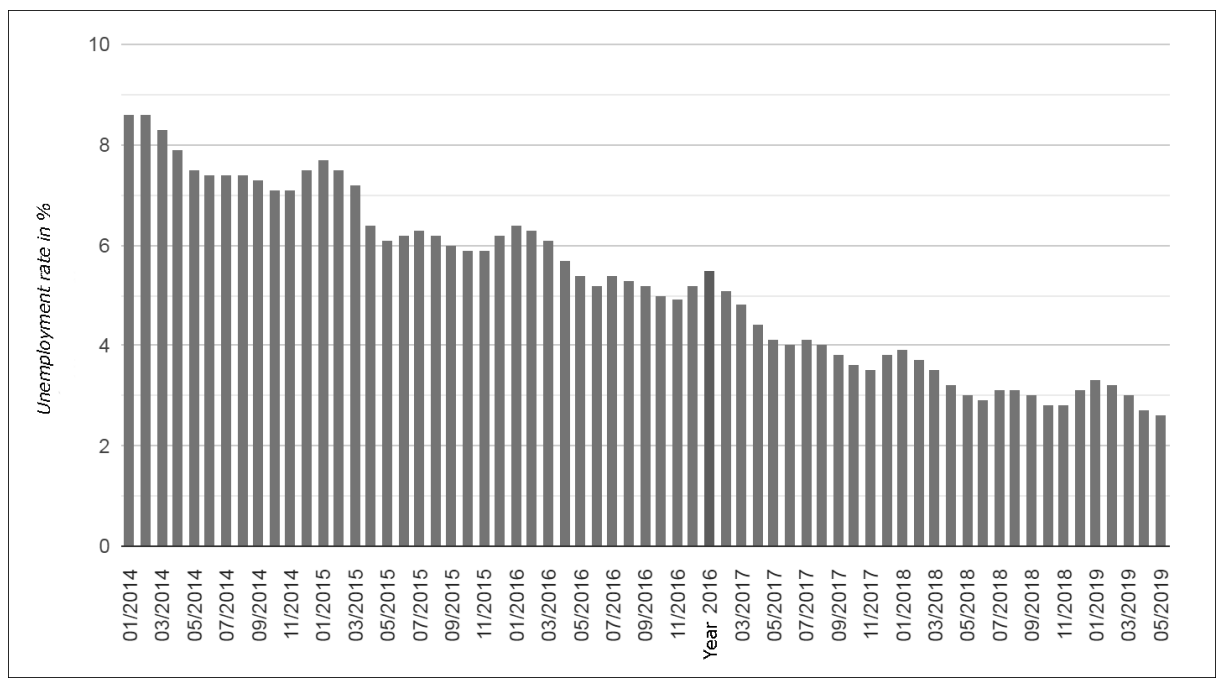

Source: Kurzy.cz(2019)

\section{Conclusion}

The purpose of this article was to show whether the Czech Republic is a welfare state or not.

As stated earlier, every modern developed country that meets the condition of a multi-party democracy, liberal economy and the existence of a certain decentralisation of government power and administration creates conditions for the emergence of a welfare state. Another already mentioned characteristic of a welfare state is the transfer of a substantial part of social activities to the state. As far as its own social attributes are concerned, the Czech Republic builds on the foundations that are based on the social policy of the first republic and which were decisively developed after 1989; today, it is the country with the lowest unemployment rates in the EU, with total public social spending oscillating around 20 percent of GDP and with citizens' expenses on health care and education being negligible.

Based on these (and also other) facts, Czechia can be generally considered a welfare state. Unfortunately, it is not possible to clearly place Czechia in one particular type of the welfare state; the Czech Republic oscillates between the liberal and the conservative type. One of the factors is certainly the relatively short period of the country's development, started in 1989 with the elementary system changes. 


\section{References}

Bauman, Z. a Bordoni, C. (2015). Stát v krizi. 1. vyd. Olomouc: Broken Books. ISBN97880-905309-7-3.

Český statistický úřad. Loni v ČR klesl počet lidí ohrožených chudobou a nedostatkem. [online]. Praha: ČTK - České noviny, 10. 4. 2018 [cit. 14. 3. 2019]. Dostupné z https:// www.ceskenoviny.cz/zpravy/loni-v-cr-klesl-pocet-lidi-ohrozenych-chudobou-a-nedostatkem/1607603.

Esping-Andersen, G. (1990). The Three Worlds of Welfare Capitalism. New Jersey: Princeton University Press. ISBN 0691028575.

Giddens, A. (2001). Třetí cesta: obnova sociální demokracie. 1. vyd. Praha: Mladá fronta. ISBN 80-204-0906-8.

Keller, J. (2011). Soumrak sociálního státu. 2. vyd. - dotisk. Praha: Sociologické nakladatelství (Slon). ISBN 978-80-7419-017-9.

Korpi, W. (1983). The Democratic Class Struggle. London: Routledge Kegan \&Paul. ISBN 978-0710094360.

Krebs, V. et al. (2010). Sociální politika. 5. přepracované a aktualizované vyd. Praha: Wolters Kluwer ČR. ISBN 978-80-7357-585-4.

Kvapilová, J. (2010). Typy státu blahobytu a Česká republika. Diplomová práce. Brno: MU ESF.

Macková, M. (2015). Deactivation of pacemacers and ICDs in the end of life. Central European Journal of Nursing and Midwifery, 6(2), 232-236.

Macková, M., Kotlán, I. (2017). Deactivation of Pacemaker: Ethical Approach or Managerial Failure? DANUBE: Law, Economics and Social Issues Review, 8(4), 229-235.

Mertl, J. (2017). Přrerozdělování welfare: nástroj pomoci nebo kontroly? 1.vyd. Brno: Doplněk. ISBN 978-80-7239-332-9.

Midgley, J. (1997). Social Welfare in Global Context. London: SAGE Publication Ltd. ISBN 0-7619-0787-4.

Musil, L. a Ogrocká, J. (1996). Vývoj sociálního státu v Evropě. Čítanka z historie moderní evropské sociální politiky. Brno: Doplněk, 1996. ISBN:80-85765-62-4.

Kurzy.cz. (2019). Nezaměstnanost v $\check{C} R$, vývoj, rok 2019 - 5 let. [online]. Praha: AliaWeb, spol. s.r.o., ISSN 1801-8688. [cit. 14. 3. 2019]. Dostupné z https://www.kurzy.cz/makroekonomika/nezamestnanost/.

OECD Statistics - Social Expenditure (SOCX). [online]. Paříž: OECD, 2019. [cit. 10. 3. 2019]. Dostupné z https://stats.oecd.org/Index.aspx?DataSetCode=SOCX_AGG.

Pick, M. (2011). Stát blahobytu, nebo kapitalismus?: my a svět v ére neoliberalismu 1989-2011. (vybrané články autora). 2. doplněné vyd. Všeň: Grimmus. ISBN 978-8087461-05-1.

Potůček, M. (1995). Sociální politika. 1. vyd. Praha: Sociologické nakladatelství (Slon). ISBN 80-85850-01-X.

Potůček, M. (2002). Sociální doktrína České republiky. [online]. Praha: Sociální politika, 2002, roč. 28, č. 1-2, s. 7-11. ISSN 0049-0962. [cit. 12. 3. 2019]. Dostupné $\mathrm{z}$ http://www.martinpotucek.cz/index.php?option=com_rubberdoc\&view=category\&id= $44 \% 3$ Aodborne-clanky\&Itemid $=64 \&$ lang $=$ cs\&limitstart $=20$. 
Potůček, M. (2005) (dotisk 2010). Veřejná politika. Upravené, doplněné a aktualizované vydání. Praha: Sociologické nakladatelství (SLON). ISBN: 80-86429-50-4; 978-8086429-50-2.

Potůček, M. (2006). Český sociální stát v postkomunistickém kontextu [online]. Praha: Centrum pro sociální a ekonomické strategie Fakulty sociálních věd Univerzity Karlovy. Předneseno na konferenci „Sociální soudržnost v zemích střední a východní Evropy a její budoucnost“" [cit. 13. 3. 2019]. Dostupné z https://docplayer.cz/223575-Cesky-socialnistat-v-postkomunistickem-kontextu.html.

Ryně̌, V. (2015). Perspektiva lidstva, člověka a sociální stát. 1. vyd. Praha: Pavel Káňa vydavatelství Knihař. ISBN 978-80-86292-75-5.

Tomeš, I. (2010). Úvod do teorie a metodologie sociální politiky. 1. vyd. Praha: Portál. ISBN 978-80-7367-680-3.

Večeřa, M. (1993). Sociální stát. Východiska a přístupy. 1. vyd. Praha: Sociologické nakladatelství (Slon). ISBN 80-901424-6-X. 